\title{
MICROBIAL CONTAMINATION OF CENTRAL SUPPLY SYSTEMS FOR MEDICAL AIR
}

\author{
Carolina Machado Andrade ${ }^{1 *}$; Tamara Brown ${ }^{2}$ \\ ${ }^{1}$ White Martins Gases Industriais Ltda, Desenvolvimento de Aplicações Medicinais, Rio de Janeiro, RJ, Brasil. \\ ${ }^{2}$ Praxair Inc., Pesquisa e Desenvolvimento na Área Medicinal, Tonawanda, NY, USA.
}

This paper corresponds to an "extended abstract" selected for oral presentation in the $22^{\text {nd }}$ Brazilian Congress of Microbiology, held in Florianópolis, SC, Brazil, in November 17-20, 2003

\begin{abstract}
There are many standards and recommendations for breathing air quality associated with respiratory protection equipment, but little has been done regarding the possible microbial contamination of medical air. The present study demonstrates quantitatively and qualitatively that pipelines might be incriminated as source of microbial contamination of compressed and synthetic air for medical use. Air samples were drawn into an especially pressure-resistant device and the bacterial and fungi contents were identified after growth on agar plates. The bacterial flora isolated from peripheral air outlets was virtually the same as that found in the central air-generating installations, consisting of a mixture of pathogens and normal skin bacteria. Several factors contributing to microbial contamination of medical air are mentioned and preventive measures are discussed.
\end{abstract}

Key words: microbial contamination, compressed air, synthetic air, medical air.

\section{INTRODUCTION}

Air is a mixture of elements and components that, at atmospheric pressure and temperature, is colorless, unscented and flavorless, according to CGA G-7 - 1990. Medical gases for use in health care facilities are typically regulated by national entities, like Brazilian Sanitary Surveillance Agency (Anvisa) in Brazil and the National Fire Protection Agency (NFPA) in the United States.

According to Anvisa (3), three types of compressed air can be found in health institutions. These include (1) Industrial compressed air that is used for cleaning and operation of equipment. (2) Medicinal compressed air, which is used for therapeutic purposes, generated by a water seal-, membrane, or dry lubricated piston compressor. The central supply system must contain filters and/or purifying apparatus, as necessary, to produce medicinal air with the maximum limits for pollutants determined by Anvisa; (3) Synthetic medicinal air is produced by mixing oxygen (21\%) and nitrogen (79\%). Synthetic medicinal air is used for therapeutic purposes as an alternative to medicinal compressed air. The central supply system for synthetic medicinal air must have oxygen and nitrogen sources meeting purity specifications compatible to those for medicinal use.

It has been recently acknowledged that microorganisms can be a contamination hazard in gases $(5,6)$, although no episode relating to contamination of medicinal gases by pathogens has been reported to this date (7). Therefore, the FDA considers Medicinal Air USP as pharmaceutical product. The European Pharmacopoeia also has suggested the classification of medicinal air as a category 2 product: a nonsterile product with contaminant concentration of $<100 \mathrm{CFU}$ (colony forming units) $/ \mathrm{m}^{3}$ of gas, free of pathogenic microorganisms. The recommendations for preventive measures include alternatives that can lead to a reduction/ control in contaminant level.

*Corresponding author. Mailing address: White Martins Gases Industriais Ltda. Rua Mayrink Veiga, 9, 26º andar. 20090-050, Rio de Janeiro RJ, Brasil.

E-mail: carolina_andrade@praxair.com 
Usually, anesthesia personnel assume that the medical gases delivered from the wall outlets in the operating room are clean, correct and safe (5), while ventilators and respiratory care systems are a known source of infection due to bacterial contamination $(10,11)$. However, owners or administrators do not easily accept the idea that the contamination source could be beyond the walls in the pipe systems, possibly due to liability issues and the need to clean the systems once the contamination is identified.

Previous preliminary sampling by Praxair Inc. and White Martins Industrial Gases investigated the presence of biological, chemical, and physical contamination in medical air. This work is a continuation of these previous investigations, focusing on the pipeline for medicinal air from compressed and synthetic sources in order to quantify microbial contamination and other contamination levels in the pipe systems.

\section{MATERIALS AND METHODS}

\section{Sites Description}

Samples were obtained from medicinal air systems of each of four Rio de Janeiro, Brazil-area hospitals. Sites are identified as Hospital I (HPI), Hospital II (HPII), Hospital III (HPIII), and Hospital IV (HPIV). HPI is a 100-bed non-profit hospital, and HPII is a 50-bed private hospital. HPIII is a clinic with less than 50 beds, while HPIV is also a private hospital with approximately 100 beds. The samples for this study were obtained from the medicinal air system located outside and in an indoor, insulated location, respectively for HPI-HPIII and for HPIV.

\section{Gas Sampling}

A portable battery-operated compressed gas sampler (SMA CA-200, Veltek, PA) was used to collect samples. A range of 15 to 84 liters of gas was pumped through the $90 \mathrm{~mm}$-plates placed inside the head of the sampler. In each sample, two types of growth media were selected, SDA (Sabouraud Dextrose Agar) and TSA (Trypticase Soya Agar).

\section{Air Quality Evaluation}

Samples from different points were collected, according to the criteria established in Resolution RE09 (4). The plates were incubated at $30-35^{\circ} \mathrm{C}$ (TSA) and $20-25^{\circ} \mathrm{C}$ (SDA), to allow the growth of bacteria and fungi, respectively. Burge et al. (8) have shown that, among the various fungal isolation media, SDA recovers the broadest range and the highest number of airborne fungal species. TSA agar was used to culture environmental bacteria; however, human commensal bacteria could also grow on it.

The total microorganism $\left(\mathrm{CFU} / \mathrm{m}^{3}\right)$ for each air sample was calculated and the ratio for each group (fungi or bacteria) determined. The three most predominant types of fungi present were identified to the genus level. The isolated bacteria and fungi were identified by standard methods.

\section{Gas Analysis}

A sample for chemical and particulate analysis was also obtained at a use point via a cylinder for laboratory processing by standard methods.

\section{Statistical Analysis}

The main effects and interactions of the variables were calculated using the software Minitab for windows, release 13.32. Coefficients smaller than two times the standard error were presumed to be due to experimental error and were therefore neglected. A total of 65 runs were necessary to estimate the sampling time and the place of sample, considering $95 \%$ confidence limit.

\section{RESULTS AND DISCUSSION}

\section{Medicinal Air Sampling (Synthetic Air Mixer)}

Fig. 1A shows the results found in the HPI. Similarly, for HPII, the average number of bacteria found in the room outlet was $32 \mathrm{cfu} / \mathrm{m}^{3}$ and the average fungi count was $1.4 \times 10^{2} \mathrm{cfu} / \mathrm{m}^{3}$ (not shown). The total average contaminant level in the emergency outlet of the pipeline and at the outlet of the mixer shown the same variances (95\% confidence limit).

\section{Background Environmental Air Sampling}

The average number of microorganisms in the ambient air within the hospital ranged from 0.8 to $1.6 \times 10^{2} \mathrm{cfu} / \mathrm{m}^{3}$ and from 0.9 to $2.0 \times 10^{2} \mathrm{cfu} / \mathrm{m}^{3}$, for bacteria and fungi, respectively. The highest bacteria count was found in the ICU (Intensive Care Unit), and the highest fungi count was found in the emergency room. HPI outdoors shows average count of $1.7 \times 10^{2} \mathrm{cfu} / \mathrm{m}^{3}$ for both bacteria and fungi. For HPII, the average number of bacteria was $8.0 \times 10^{2} \mathrm{cfu} / \mathrm{m}^{3}$ outdoors and $1.7 \times 10^{2} \mathrm{cfu} / \mathrm{m}^{3}$ within the hospital room. The average fungi count was $1.4 \times 10^{2} \mathrm{cfu} / \mathrm{m}^{3}$ outdoors and $2.6 \times 10^{2} \mathrm{cfu} / \mathrm{m}^{3}$, within the room. The exact location where the samples were collected may have an effect on the total amount of microorganisms, which could explain the good correlation observed between the number of microorganisms observed in the mixer compared with the microorganisms found in the environmental air. The results show no difference in the contaminant level next to the mixer or in the room $(p<0.05)$, indicating the non-existence of amplification sites inside the pipeline. According to Moss (5), contamination can be present in the compressed air from three sources. These are namely, the atmosphere, the compressor and the distribution equipment. In the case of synthetic air, it must be considered just the atmosphere and the distribution equipment, since it is considered that Medical Air USP is as pharmaceutical product.

\section{Medicinal Air Sampling (Compressor)}

The average number of microorganisms at the compressor at HPIII was $88 \mathrm{cfu} / \mathrm{m}^{3}$ and $14 \mathrm{cfu} / \mathrm{m}^{3}$, while the sample of air taken 

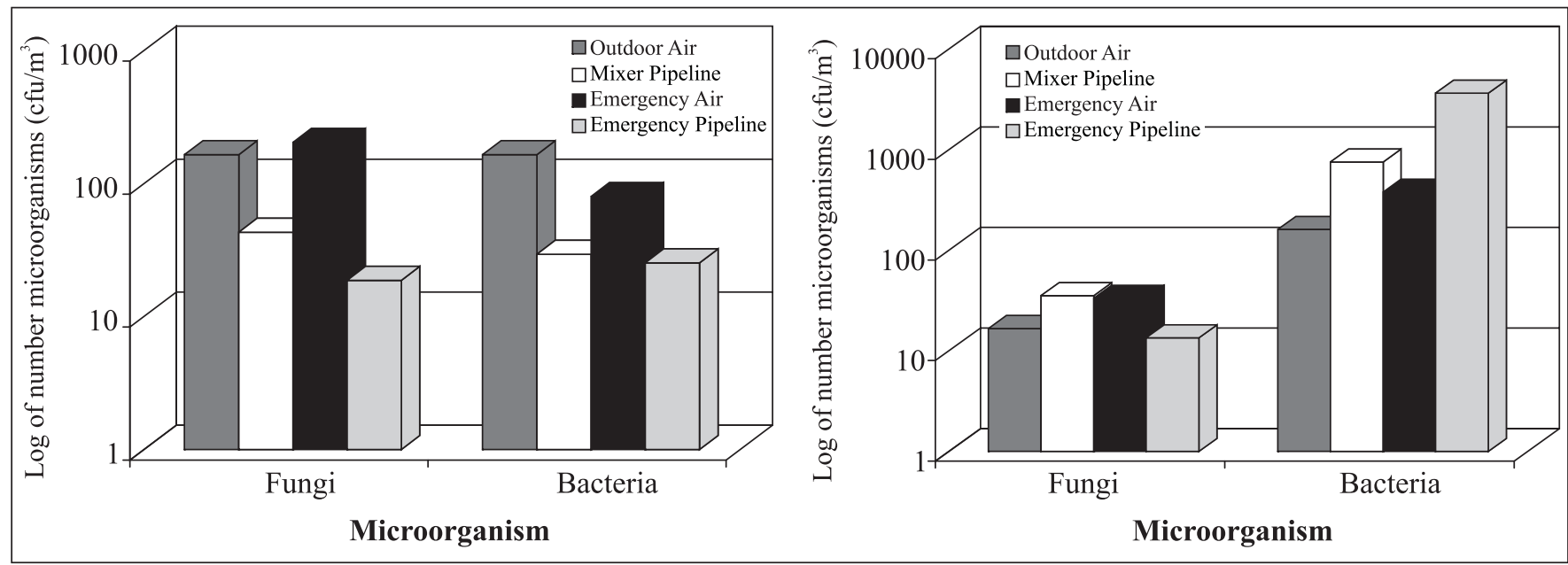

Figure 1. Microorganism Count in Medical Air Samples HPI (A) and HPIV (B). The samples were collected as described in Methodology. Each bar represents the average of different sampling. CFU: colony-forming units.

from an outlet in the material preparation room was $55 \mathrm{cfu} / \mathrm{m}^{3}$ and $12 \mathrm{cfu} / \mathrm{m}^{3}$, for bacteria and fungi, respectively (not shown). Fig. 1B shows for HPIV a higher average number of bacteria at the compressor and in an outlet in the procedure room.

\section{Background Environmental Air Sampling}

The average number of bacteria found outdoors (HPIV) was $160 \mathrm{cfu} / \mathrm{m}^{3}$ and fungal count was $17 \mathrm{cfu} / \mathrm{m}^{3}$. Indoor air samples showing bacterial range from 1.2 to $3.8 \times 10^{2} \mathrm{cfu} / \mathrm{m}^{3}$ and fungal count from 0.33 to $1.0 \times 10^{2} \mathrm{cfu} / \mathrm{m}^{3}$.

The microbial contamination detected in HPIII can be explained by the presence of microorganisms normally detected in the external air, showing also a good correlation between the microorganism count from the compressor and in the preparation room. Indeed, for HPIV the higher number of bacteria found in the outlet is due probably to the presence of amplification points of these microorganisms, existing inside the pipeline, as biofilm. The formation of biofilm in those conditions results from a combination of microbial spores, organic matter as well as humidity. Table 1 lists the microorganisms found in mixers, central air compressors and peripheral air outlets.

The bacterial flora isolated from peripheral air outlets is virtually the same as that found in the central air-generating installations, being a mixture of pathogens and normal skin bacteria. However, it must be emphasized that, when supplied directly into the tracheas of seriously ill patients, no sharp distinction between pathogenic and non-pathogenic bacteria can be maintained (6).

\section{Physical-Chemical Characterization of Medical Air}

Results from three of the four hospitals demonstrate the compliance of the samples with the standards for medicinal air
Table 1. Bacterial and Fungic Contaminants found in Medicinal Air Systems.

\begin{tabular}{|c|c|c|c|}
\hline Sample & Site & $\begin{array}{l}\text { Bacterial prominent } \\
\text { species }\end{array}$ & $\begin{array}{c}\text { Fungic } \\
\text { prominent } \\
\text { species }\end{array}$ \\
\hline $\begin{array}{c}\text { HPI } \\
\text { Pipeline }\end{array}$ & Mixer & $\begin{array}{c}\text { Staphylococcus sp. } \\
\text { Micrococcus luteus } \\
\text { Bacillus coagulans } \\
\text { Gram Negative Rods }\end{array}$ & Aspergillus sp. \\
\hline \multirow{2}{*}{$\begin{array}{c}\text { HPII } \\
\text { Pipeline }\end{array}$} & Mixer & $\begin{array}{c}\text { Staphylococcus sp. } \\
\text { Micrococcus luteus } \\
\text { Bacillus coagulans } \\
\text { Gram Negative Rods }\end{array}$ & ND \\
\hline & $\begin{array}{l}\text { Emergency } \\
\text { Room }\end{array}$ & $\begin{array}{l}\text { Micrococcus luteus } \\
\text { Gram Negative Rods } \\
\text { Staphylococcus scuri }\end{array}$ & ND \\
\hline \multirow[t]{2}{*}{$\begin{array}{c}\text { HPIII } \\
\text { Pipeline }\end{array}$} & Compressor & $\begin{array}{l}\text { Staphylococcus sp. } \\
\text { Staphylococcus scuri } \\
\text { Micrococcus luteus } \\
\text { Bacillus coagulans } \\
\text { Bacillus mycoides } \\
\text { Gram Negative Rods }\end{array}$ & $\begin{array}{l}\text { Aspergillus } \\
\text { niger }\end{array}$ \\
\hline & $\begin{array}{c}\text { Material } \\
\text { Preparation }\end{array}$ & $\begin{array}{c}\text { Bacillus mycoides } \\
\text { Micrococcus luteus }\end{array}$ & ND \\
\hline
\end{tabular}

(Table 2). HPIV had one exception, the dewpoint of the sample. The reason for finding live microorganisms, especially bacteria in the samples from HPIV-compressor could also be explained by the fact that a refrigerated dryer, which provides a less dry outtake air, followed the air compressor. As microorganisms 
Table 2. Physical-Chemical Characterization of Medical Air.

\begin{tabular}{|c|c|c|c|c|}
\hline \multirow{2}{*}{ Substance } & \multicolumn{2}{|c|}{ Mixer } & \multicolumn{2}{|c|}{ Compressor } \\
\hline & HPI & HPII & HPIII & HPIV \\
\hline $\mathrm{O}_{2}$ & $21.50 \%$ & $21.30 \%$ & $21.30 \%$ & $20.90 \%$ \\
\hline $\begin{array}{c}\text { Total } \\
\text { Hydrocarbon } \\
\text { Content }\end{array}$ & $2.6 \mathrm{ppm}$ & $2.4 \mathrm{ppm}$ & $2.7 \mathrm{ppm}$ & $2.1 \mathrm{ppm}$ \\
\hline $\mathrm{CO}$ & $<0.3 \mathrm{ppm}$ & $<0.3 \mathrm{ppm}$ & $<0.3 \mathrm{ppm}$ & $<0.3 \mathrm{ppm}$ \\
\hline $\mathrm{CO}_{2}$ & $<0.2 \mathrm{ppm}$ & $<0.2 \mathrm{ppm}$ & $256 \mathrm{ppm}$ & 388 ppm \\
\hline $\mathbf{N o}_{\mathbf{x}}$ & $0.1 \mathrm{ppm}$ & $<0.1 \mathrm{ppm}$ & $<0.1 \mathrm{ppm}$ & $0.1 \mathrm{ppm}$ \\
\hline Odor & None & None & None & $\begin{array}{l}\text { None } \\
-25 \mathrm{C}\end{array}$ \\
\hline Dewpoint & $<-40 \mathrm{C}$ & $<-40 \mathrm{C}$ & ND & $\begin{array}{l}\text { ( } 900 \mathrm{ppm} \\
\text { of water) }\end{array}$ \\
\hline
\end{tabular}

* out of specification.

need water for development, this humidity might explain the growth of bacteria inside the pipeline; consequently, this may compromise the quality of the medicinal air.

\section{CONCLUSIONS}

Medical compressed air can vary widely in quality depending on the installation and the provision of purification equipment (9). Poor quality compressed air has resulted in fatalities in a number of countries, particularly when the dryness of the air has not been fully considered. Water accumulating in medicinal air as a result of malfunctioning dryers can come out as air, as dewpoint changes occur along the pipeline course.

Although the synthetic medicinal air meets the category 2 product, according to the European Pharmacopoeia, special attention must be paid to blind loops in extensive pipelines systems and other locations suitable for trapping and proliferation of bacteria. Pipelines should not only be certified for gas identification, but also for contamination. Besides, user comfort is also an important consideration, since moist air can cause discomfort during exertion when working with respiratory protection equipment by causing condensation to occur on the visor or inside the suit.

It is hoped that more might be learned about microbial contamination and its prevention and treatment. Additionally, medical staff should be aware of the design, location and problems that may affect life-support systems with which they work in a daily basis, as well as what is beyond the walls and out of sight, like supply systems for medicinal air.

\section{RESUMO}

\section{Contaminação microbiana dos sistemas centrais de abastecimento de ar medicinal}

Existem vários padrões e recomendações para a qualidade do ar respirável relacionado aos equipamentos de proteção respiratória, mas pouco tem sido feito em relação a uma possível contaminação microbiana do ar medicinal. O presente trabalho demonstra quantitativa e qualitativamente que as linhas de ar estão relacionadas à contaminação microbiológica do ar comprimido e ar sintético para uso medicinal. Amostras de ar foram coletadas por um equipamento especialmente resistente a pressão, e o conteúdo bacteriano e fúngico foi identificado após crescimento em placa. A flora bacteriana isolada tanto dos sistema periféricos de ar foi virtualmente a mesma encontrada nas instalações centralizadas, sendo uma mistura de patógenos e bactérias normais da pele. Vários fatores contribuintes para a contaminação microbiana do ar medicinal e medidas preventivas são discutidas.

Palavras-chave: contaminação microbiana, ar comprimido, ar sintético, ar medicinal.

\section{REFERENCES}

1. Morris, G.K.; Shelton, B.G. A suggested air sampling strategy for microorganisms in office settings. Pathogen Control Associates, Inc., Technical Bulletin 2.4, 1994.

2. Macher, J.M. Air sampling methods for biological contaminants. Indoor Air Quality Program, Air \& Industrial Hygiene Laboratory, California Department of Health Services, Berkeley, California, 2000.

3. ANVISA. Brazilian Guidelines for design, installation and evaluation of projects in the health institutions. Resolution RDC 50, February $21,2002$.

4. ANVISA. Brazilian Guidelines for IAQ. Resolution RE $\mathrm{n}^{\circ}$ 9, January $16,2003$.

5. Moss E. Medical gas contamination: an unrecognized patient danger. Anesthesia Patient Safety Foundation Newsletter, 9(2):73-76, 1994.

6. Bjerring, P.; Oberg, B. Bacterial contamination of compressed air for medical use. Anaesthesia, 41:148-150, 1986.

7. Duane, S. Policy Questions on Medical Gases, Human Drug CGMP Notes, FDA, 1997.

8. Burge H.P.; Solomon W.R.; Boise J.R. Comparative merits of eight popular media in aerometric studies of fungi, J. Allergy. Clin. Immunol., 60:199-203, 1977.

9. Billiet, C.T.; Fielding, R.M. Breathable air from compressed air systems. Domnick Hunter 1992, Publication Reference 38, 2/92/UK.

10. Swk, I.; Fung, J.P.H.; Yu, D.Y.C. Unusual dissemination of Pseudomonas by ventilators. Anaesthesia, 37: 1074-7, 1982.

11. Garibaldi, R.A.; Britt, M.R.; Webster, C.; Paice, N.L. Failure of bacterial filters to reduce the incidence of pneumonia after inhalation anesthesia. Anesthesiology, 54:369-72, 1981. 